\title{
ANALISIS KESALAHAN SINTAKSIS DALAM TEKS EKSPLANASI SISWA KELAS XI SMA NEGERI 3 MEDAN TAHUN PEMBELAJARAN 2016/2017
}

\author{
Oleh \\ Armaini Suryana (armainisuryana@gmail.com) \\ Drs. Basyaruddin, M.Pd.
}

\begin{abstract}
ABSTRAK
Penelitian ini dilaksanakan di SMA Negeri 3 Medan pada semester genap tahun pembelajaran 2016/2017 di kelas XI dengan tujuan untuk mendeskripsikan bentuk-bentuk kesalahan sintaksis meliputi: (1) kesalahan sintaksis berupa penggunaan frasa berdasarkan faktor penyebabnya dalam teks eksplanasi siswa. (2) kesalahan sintaksis berupa penggunaan kalimat berdasarkan faktor penyebabnya dalam teks eksplanasi siswa. Subjek penelitian ini adalah teks eksplanasi yang ditulis oleh siswa kelas XI MIA 2 berjumlah 44 teks.Metode yang digunakan dalam penelitian ini adalah metode deskriptif kualitatif. Teknik pengumpulan data dalam penelitian ini adalah analisis dokumen dengan cara membaca dan mencatat. Instrumen pada penelitian ini adalah peneliti sendiriyaitu sebagai instrumen kunci dengan bantuan instrumen pendukung yaitu tes esai. Hasil penelitian kesalahan sintaksis dalam teks eksplanasi siswa kelas XI SMA Negeri 3 Medan, yaitu (1) kesalahan sintaksis berupa penggunaan frasa sejumlah 61 kalimat $(42,95 \%)$, (2)kesalahan sintaksis berupa penggunaan kalimat sejumlah 81 kalimat $(57,04 \%)$.
\end{abstract}

\section{Kata Kunci :Teks Eksplanasi, Kesalahan Sintaksis, Analisis}

\section{PENDAHULUAN}

Pendidikan di Indonesia menempatkan bahasa Indonesia sebagai salah satu bidang studi yang diajarkan di sekolah. Pembelajaran bahasa Indonesia di sekolah pada dasarnya menekankan siswa untuk mampu berbahasa dan bersastra.Pada hakikatnya belajar bahasa adalah berkomunikasi. Oleh karena itu, pembelajaran bahasa dan sastra Indonesia diarahkan untuk meningkatkan kemampuan berkomunikasi siswasecara lisan maupun tulis dengan baik dan benar.

Kebijakan yang dilakukan pemerintah dalam kurikulum 2013, tidak hanya menjadikan pelajaran bahasa Indonesia berada dalam daftar pelajaran di sekolah 
saja, melainkan telah dirancang ke dalam pembelajaran berbasis teks.Menurut Mahsun (2014:1)“Teks merupakan satuan bahasa yang digunakan sebagai ungkapan suatu kegiatan sosial baik secara lisan maupun tulis dengan struktur berpikir yang lengkap."

Makna kalimat dalam suatu teks dapat dipahami oleh pembaca jika penulis mengetahui aturan atau kaidah bahasaIndonesia yang baik dan benar. Bahasa Indonesia yang baik adalah bahasa yang digunakan sesuai dengan normakemasyarakatan yang berlaku,sedangkan bahasa Indonesia yang benar adalah bahasa Indonesia yang sesuai dengan aturan atau kaidah bahasa Indonesia yang berlaku.

Salah satu pembahasan bahasa Indonesia berbasis teks dalam kurikulum 2013 yaitu teks eksplanasi yang terdapat pada materi pelajaran kelas XI SMA dengan kompetensi dasar 4.4 memproduksi teks eksplanasi secara lisan atau tulis dengan memperhatikan struktur dan kebahasaan. Siswa dituntut untuk mampu memproduksi atau menghasilkan teks eksplanasi baik secara lisan maupun tulis.Hal tersebut tentunya menuntut bahwa isi teks harus terdiri dari kalimatkalimat yang sistematis sesuai dengan aturan tata bahasa Indonesia. Menurut Kosasih (2014:178) "Eksplanasi merupakan teks yang menjelaskan suatu proses atau peristiwa tentang asal-usul, proses, atau perkembangan suatu fenomena, mungkin berupa peristiwa alam, sosial, ataupun budaya."

Banyaknya kesalahan berbahasa terutama pada tata kalimat atau sintaksis ini telah dilakukan oleh penelititerdahulu seperti Istinganah (2012:88) dengan judul "Analisis KesalahanSintaksis pada Karangan Narasi Ekspositoris Siswa KelasVIII SMP Negeri 1Banguntapan, Bantul, Yogyakarta." Hasil penelitian tersebut sebagai berikut pertama, kesalahan penggunaan struktur frasa meliputi enam kesalahan, yaitu: penggunaan preposisi yang tidak tepat, susunan kata yang tidak tepat, penggunaan unsur yang berlebihan atau mubazir, penggunaan bentuk superlatif yang berlebihan, penjamakan ganda, dan penggunaan bentuk resiprokal yang tidak tepat. Kedua, kesalahan penggunaan struktur kalimat meliputi tujuh kesalahan, yaitu: kalimat tidak berpredikat, kalimat tidak bersubjek dan tidak berpredikat (kalimat tak lengkap), subjek ganda, penggunaan preposisi pada verba 
transitif, kalimat yang rancu, penghilangan konjungsi, dan penggunaan konjungsi yang berlebihan.

Penelitian yang dilakukan oleh Wardani (2016:11) dengan judul "Analisis Kesalahan Berbahasa pada Bidang Sintaksis dalamKarangan Deskripsi Siswa Kelas X SMK Pelita Bangsa Boyolali." Hasil penelitiannya adalah bentuk kesalahan pada bidang sintaksis dalam menulis karangan deskripsi terbagi menjadi sembilan bentuk kesalahan yaitu, kalimat berstruktur tidak baku 10 kesalahan, kalimat ambigu 3 kesalahan, kalimat yang tidak jelas 4 kesalahan, diksi yang tidak tepat dalam membentuk kalimat 11 kesalahan, kontaminasi kalimat 4 kesalahan, koherensi 2 kesalahan, kata mubazir 17 kesalahan, penggunaan kata serapan 1 kesalahan, logika kalimat 8 kesalahan.

Observasi yang dilakukan oleh peneliti pada proses belajar mengajar. Siswa ditugaskan untuk menulis teks dengan diberikan tema tertentu, namun pada kemampuan menulis siswa tidak ditekankan pada tata cara penyusunan kalimat yang benar. Banyak siswa kurang memahami penulisan kalimat yang benar. Hal tersebut dapat mempengaruhi nilai mereka terutama pada menulis teks.

Kesalahan berbahasa disebabkan oleh faktor kompetensi, artinya siswa memang belum memahami sistem linguistik bahasa yang digunakannya.Kesalahan berbahasa biasanya terjadi secara konsisten dan sistematis.Kesalahanberbahasa yang dibuat siswa merupakan suatu bagian belajar yang tidakdihindarkan.Setyawati (2013:15-16) menyatakan bahwa,"Analisis kesalahan berbahasa adalah prosedur kerja yang biasa digunakan oleh peneliti atau guru bahasa yang meliputi: kegiatan mengumpulkansampel kesalahan, mengidentifikasi kesalahan yang terdapat dalam sampel, menjelaskan kesalahan tersebut, mengklasifikasi kesalahan tersebut, dan mengevaluasi taraf keseriusan kesalahan itu."

Dengan kata lain, guru dan orang tua tidak perlu menghindar dari kesalahan, tetapi justru harus menghadapi serta memperbaiki kesalahan yang dilakukan oleh murid dan anak mereka. Semakin tinggi tingkat kesalahan belajar siswa, maka semakin rendah tingkat pencapaian tujuan pengajaran bahasanya. Kita hendaklah benar-benar menyadarkan bahwa orang tidak dapat belajar bahasa 
tanpa sama sekali berbuat kesalahan-kesalahan secara sistematis. Kesalahan berbahasa ini dapat dikurangi oleh para guru dengan membuat latihan-latihan remedial untuk para pelajarnya yang memusatkan perhatian pada kesalahankesalahan umum para pelajar, baik dalam hal struktur dan kosakata maupun unsur-unsur nonstruktural.

Permasalahan yang dijelaskan di atas akhirnya membuat peneliti merasa tertarik untuk melakukan penelitian dengan judul "Analisis Kesalahan Sintaksis dalam Teks Eksplanasi Siswa Kelas XI SMA Negeri 3 Medan TahunPembelajaran 2016/2017."

\section{METODE PENELITIAN}

Metode yang digunakan dalam penelitian ini adalah metode deskriptif kualitatif.Menurut Bogdan danTaylor (dalam Moleong, 2009:4) "Metodologikualitatif sebagai prosedur penelitian yang menghasilkan data deskriptif berupa kata-kata tertulis atau lisan dari orang-orang dan perilaku yang dapat diamati."

Penelitian ini dilakukan dengan cara mendeskripsikan dan menjelaskan kesalahan sintaksis berupa penggunaan frasa dan penggunaan kalimat dalam teks eksplanasi siswa kelas XI SMA Negeri 3 Medan guna membantu siswa dalam memahami penggunaan frasa dan kalimat dalam teks eksplanasi yang ditulis oleh siswa sehingga siswa dapat menulis sebuah teks yang baik dan benar sesuai dengan tata bahasa yang ditetapkan.

\section{HASIL PENELITIAN DAN PEMBAHASAN}

\section{A. HASIL PENELITIAN}

1. Kesalahan Sintaksis Berupa Penggunaan Frasa

a. Adanya Pengaruh Bahasa Daerah

Kesalahan ini tidak ditemukan sama sekali dalam teks yang ditulis oleh siswa.

\section{b. Penggunaan Preposisi yang Tidak Tepat}


Kesalahan ini bejumlah 18 kalimat. Bentuk yang salah:Salju adalah sebuah fenomena alam yang hanya dijumpai pada negara-negara yang memiliki iklim subtropis. (T6.P1.K1)Bentuk yang benar:Salju adalah sebuah fenomena alam yang hanya dijumpai $d i$ negara-negara yang memiliki iklim subtropis.

\section{c. Susunan Kata yang Tidak Tepat}

Kesalahan ini berjumlah 2 kalimat. Bentuk yang salah: Ini tempatdikenal dengan lingkaran api karena banyaknya gunung berapi di daerah tersebut. (T25.P4.K2)Bentuk yang benar: Tempat ini dikenal dengan lingkaran api karena banyaknya gunung berapi di daerah tersebut.

\section{d. Penggunaan Unsur yang Berlebihan atau Mubazir}

Kesalahan ini berjumlah 16 kalimat. Bentuk yang salah:Para ilmuwan pun juga mencemaskan kerugian itu. (T1.P1.K5)Bentuk yang benar: Para ilmuwan pun mencemaskan kerugian itu.Para ilmuwan juga mencemaskan kerugian itu.

\section{e. Penggunaan Bentuk Superlatif yang Berlebihan}

Kesalahan ini berjumlah 9 kalimat. Bentuk yang salah:Angin topan sangat berbeda sekali dengan angin lainnya. (T4.P3.K4)Bentuk yang benar:Angin topan sangat berbedadengan angin lainnya.Angin topan berbeda sekali dengan angin lainnya.

\section{f. Penjamakan yang Ganda}

Kesalahan ini berjumlah 12 kalimat. Bentuk Tidak Baku:Setiap memasuki musim panas banyak benda-benda beterbangan.(T12.P2.K2)Bentuk yang benar:Setiap memasuki musim panas banyak benda beterbangan. Setiap memasuki musim panas benda-benda beterbangan.

\section{g. Penggunaan Bentuk Resiprokal yang Tidak Tepat}

Kesalahan ini berjumlah 4 kalimat. Bentuk yang salah:Pembunuhan itu di mulai dari pertikaian selanjutnya saling benci-membenci. (T7.P3.K4)Bentuk yang benar:Pembunuhan itu di mulai dari pertikaian selanjutnya saling membenci. Pembunuhan itu di mulai dari pertikaian selanjutnya benci-membenci.

\section{Kesalahan Sintaksis Berupa Penggunaan Kalimat}




\section{a. Kalimat Tidak Bersubjek}

Kesalahan ini berjumlah 2 kalimat.Bentuk yang salah:Pada materialmaterial yang meleleh ini menghasilkan gas yang bercampur dengan magma. (T19.P2.K4)Bentuk yang benar:Pada material-material yang meleleh ini dihasilkan gas yang bercampur dengan magma. Material-material yang meleleh ini menghasilkan gas yang bercampur dengan magma.

\section{b. Kalimat Tidak Berpredikat}

Kesalahan ini berjumlah 8 kalimat. Bentuk yang salah:Angin yang panas membakar puing-puing bangunan dan benda-benda yang ikut terbang serta menciptakan tornado api yang panas dan dahsyat. (T21.P2.K6)Bentuk yang benar: Angin yang panas itu membakar puing-puing bangunan dan benda-benda yang ikut terbang serta menciptakan tornado api yang panas dan dahsyat.

\section{c. Kalimat Tidak Lengkap (Tidak Bersubjek dan Tidak Berpredikat)}

Kesalahan ini berjumlah 23 kalimat.Bentuk yang salah:Seperti alam atau karena ulah manusia. (T3.P2.K4)Bentuk yang benar: Selain itu, tanah longsor juga dipicu oleh hal lain, seperti oleh alam atau karena ulah manusia

\section{d. Penggandaan subjek}

Kesalahan ini berjumlah 1.Bentuk yang salah:Pemukiman kumuh itu masyarakat yang tinggal umumnya terdiri dari golongan-golongan yang gagal mencapai kehidupan yang layak. (T9.P2.K2)Bentuk yang benar:Masyarakat yang tinggal di pemukiman kumuhitu umumnya terdiri dari golongan-golongan yang gagal mencapai kehidupan yang layak. (kalimat aktif)

\section{e. Antara Predikat dan Objek yang Tersisipi}

Kesalahan ini berjumlah 3 kalimat. Bentuk yang salah:Pemerintah danmasyarakat harus bersungguh-sungguh memberantas tentang narkoba. (T20.P4.K4)Bentuk yang benar:Pemerintah dan masyarakat harus bersungguhsungguh memberantas narkoba.

\section{f. Kalimat yang Tidak Logis}

Kesalahan ini berjumlah 2 kalimat. Bentuk yang salah:Banjir sering terjadi disebabkan oleh gundulnya hutan dan sungai yang sudah tidak teratur lagi akan tetapi gundulnya hutan tersebut juga. (T14.P3.K1)Bentuk yang benar: 
Banjir sering terjadi disebabkan olehpenebangan pohon sampai hutan menjadi gundul dan pencemaran air di sungai.

\section{g. Kalimat yang Ambiguitas}

Kesalahan ini tidak ada ditemukan dalam teks yang ditulis siswa.

\section{h. Penghilangan Konjungsi}

Kesalahan ini berjumlah 9 kalimat.Bentuk yang salah: Kita tidak menyadari (...) setiap hari terjadi penumpukan sampah. (T16.P2.K1)Bentuk yang benar:Kita tidak menyadari bahwa setiap hari terjadi penumpukan sampah.

\section{i. Penggunaan Konjungsi yang Berlebihan}

Kesalahan ini berjumlah 11 kalimat.Bentuk yang salah: Untuk menghindari banyak korban, maka perlu dilakukan usaha-usaha penanggulangan bencana. (T2.P4.K2)Bentuk yang benar: Untuk menghindari banyak korban, perlu dilakukan usaha-usaha penanggulangan bencana.

\section{j. Urutan yang Tidak Paralel}

Kesalahan ini berjumlah 10 kalimat. Bentuk yang salah: Pelayanan dasar itu dapat diwujudkan dengan meningkatkan sumber air bersih, memperbaiki rumah dan penyediaan usaha. (T9.P4.K2)Bentuk yang benar:Pelayanan dasar itu dapat diwujudkan dengan peningkatan sumber air bersih, perbaikan rumah, dan penyediaan usaha.

\section{k. Penggunaan Istilah Asing}

Kesalahan ini berjumlah 4 kalimat. Bentuk yang salah: Jenis awan berlapislapis ini menjulang ke arah vertikal sampai ketinggian 30.000 feet. (T5.P3.K3)Bentuk yang benar:Jenis awan berlapis-lapis ini menjulang ke arah vertikal sampai ketinggian 30.000 kaki.

\section{Penggunaan Kata Tanya yang Tidak Perlu}

Kesalahan ini berjumlah 8 kalimat. Bentuk yang salah: Gunung berapi adalah sebuah titik pusat yang manasewaktu-waktu dapat meletus. (T2.P1.K1)Bentuk yang benar:Gunung berapi adalah sebuah titik pusat yang sewaktu-waktu dapat meletus.

\section{B. PEMBAHASAN}




\section{Kesalahan Sintaksis Berupa Penggunaan Frasa \\ a. Adanya Pengaruh Bahasa Daerah}

Kesalahan ini tidak ditemukan sama sekali dalam teks yang ditulis oleh siswa. Hal ini menunjukkan bahwa siswa di sekolah tersebut sudah tidak terpengaruh menggunakan bahasa daerah dalam menulis teks.

\section{b. Penggunaan Preposisi yang Tidak Tepat}

Kesalahan pada kalimat "Salju adalah sebuah fenomena alam yang hanya dijumpai pada negara-negara yang memiliki iklim subtropis.” (T6.P1.K1) yaitu penggunaan preposisi pada tidak tepatjika diikuti kata "negara" karena pada merupakan preposisi yang digunakan untuk menyatakan waktu, sedangkan kata "negara" menyatakan tempat. Preposisi yang tepat untuk menyatakan tempat yaitu di. Bentuk yang benar:Salju adalah sebuah fenomena alam yang hanya dijumpai di negara-negara yang memiliki iklim subtropis.

\section{c. Susunan Kata yang Tidak Tepat}

Kesalahan pada kalimat "Ini tempatdikenal dengan lingkaran api karena banyaknya gunung berapi di daerah tersebut. (T25.P4.K2).” yaitu susunan kata ini tempattidak tepat. Kata ini tempat merupakan terjemahan dari bahasa Inggris yaitu this is the place. Bentuk yang benar: Tempat ini dikenal dengan lingkaran api karena banyaknya gunung berapi di daerah tersebut.

\section{d. Penggunaan Unsur yang Berlebihan atau Mubazir}

Kesalahan pada kalimat "Para ilmuwan pun juga mencemaskan kerugian itu." (T1.P1.K5) yaitu penggunaan kata pun jugamubazir. Kata pun berarti "demikian juga" dan "meski". Begitu juga dengan kata juga yang berarti "demikian halnya", "serupa atau sama." Perbaikannya adalah dengan menggunakan salah satudi antaranya.Bentuk yang benar: Para ilmuwan pun mencemaskan kerugian itu.Para ilmuwan juga mencemaskan kerugian itu.

\section{e. Penggunaan Bentuk Superlatif yang Berlebihan}

Kesalahan pada kalimat "Angin topan sangat berbeda sekali dengan angin lainnya."(T4.P3.K4)yaitu penggunaan bentuk superlatif yang berlebihan pada kata sangat berbeda sekali. Dalam pemakaiannya, dapat dipilih salah satu dari bentuk superlatif tersebut jika sudah menggunakan kata sangat, tidak perlu 
menggunakan kata sekali. Bentuk yang benar:Angin topan sangat berbedadengan angin lainnya.Angin topan berbeda sekali dengan angin lainnya.

\section{f. Penjamakan yang Ganda}

Kesalahan pada kalimat "Setiap memasuki musim panas banyak bendabenda beterbangan."(T12.P2.K2)adalah terdapat penggunaan penanda jamak yang ganda pada kata banyak benda-benda. Dalam sebuah kalimat untuk penanda jamak sebuah kata cukup menggunakan satu penanda saja. Bentuk yang benar:Setiap memasuki musim panas banyak benda beterbangan. Setiap memasuki musim panas benda-benda beterbangan.

\section{g. Penggunaan Bentuk Resiprokal yang Tidak Tepat}

Kesalahan pada kalimat "Pembunuhan itu di mulai dari pertikaian selanjutnya saling benci-membenci."(T7.P3.K4) adalah terdapat penggunaan resiprokal yang tidak tepat pada kata saling benci-membenci. Dalam pemakaiannya, ditentukan pilihan yaitu jika menggunakan kata saling dengan kata berimbuhan atau jika menggunakan kata ulang berimbuhan tanpa ada kata saling. Bentuk yang benar:Pembunuhan itu di mulai dari pertikaian selanjutnya saling membenci. Pembunuhan itu di mulai dari pertikaian selanjutnya benci-membenci.

\section{Kesalahan Sintaksis Berupa Penggunaan Kalimat}

\section{a. Kalimat Tidak Bersubjek}

Kalimat tidak bersubjek pada kalimat "Pada proses pembekuan itu membentuk kristalan-kristalan kecil yang kemudian turun ke bumi."(T19.P2.K4)Perbaikan kalimat tersebut dapat dilakukan dengan dua cara yaitu (a) jika ingin tetap mempertahankan preposisi yang mendahului subjek, predikat diubah menjadi bentuk pasif, dan (b) jika menghendaki predikat dalam bentuk aktif, preposisi yang mendahului subjek harus dihilangkan. Bentuk yang benar:Pada material-material yang meleleh ini dihasilkan gas yang bercampur dengan magma. Material-material yang meleleh ini menghasilkan gas yang bercampur dengan magma.

\section{b. Kalimat Tidak Berpredikat}


Kalimat tidak berpredikat pada kalimat "Angin yang panas membakar puingpuing bangunan dan benda-benda yang ikut terbang serta menciptakan tornado api yang panas dan dahsyat."(T21.P2.K6)Jika kata yang tidakdihilangkan, kalimat tersebut dapat memiliki predikat apabila nomina padakalimat itu didampingi oleh kata itu,ialah, adalah, atau merupakan.Bentuk yang benar: Angin yang panas itu membakar puing-puing bangunan dan benda-benda yang ikut terbang serta menciptakan tornado api yang panas dan dahsyat.

\section{c. Kalimat Tidak Lengkap (Tidak Bersubjek dan Tidak Berpredikat)}

Kalimat yang tidak lengkap pada kalimat "Sepertioleh alam atau karena ulah manusia.”(T3.P2.K4)Kalimat tersebut merupakan kalimat yang tidak lengkap, karena kalimat tersebut merupakanketerangan kalimat sebelumnya.Bentuk yang benar: Selain itu, tanah longsor juga dipicu oleh hal lain, seperti oleh alam atau karena ulah manusia

\section{d. Penggandaan subjek}

Penggandaan subjek pada kalimat "Pemukiman kumuh itu masyarakat yang tinggal umumnya terdiri dari golongan-golongan yang gagal mencapai kehidupan yang layak." (T9.P2.K2) Perbaikan kalimat tersebut dapat dilakukan dengan cara: (a) diubah menjadi kalimat pasif bentuk diri, (b) diubah menjadi kalimat aktif yang normatif.Bentuk yang benar:Masyarakat yang tinggal di pemukiman kumuhitu umumnya terdiri dari golongan-golongan yang gagal mencapai kehidupan yang layak. (kalimat aktif)

\section{e. Antara Predikat dan Objek yang Tersisipi}

Antara Predikat dan Objek yang Tersisipi pada kalimat "Pemerintah danmasyarakat harus bersungguh-sungguh memberantas tentang narkoba. (T20.P4.K4)Pada kalimat verba transitif seharusnya antara predikat dan objek tidak perlu disisipi preposisi.Bentuk yang benar:Pemerintah dan masyarakat harus bersungguh-sungguh memberantas narkoba.

\section{f. Kalimat yang Tidak Logis}

Kalimat yang tidak logis "Banjir sering terjadi disebabkan oleh gundulnya hutan dan sungai yang sudah tidak teratur lagi akan tetapi gundulnya hutan tersebut juga. (T14.P3.K1)Pada kalimat di atas, ketidaklogisan terletak pada 
makna kata gundulnya hutan dan sungai yang sudah tidak teratur lagi akan tetapi gundulnya hutan tersebut juga. Kata gundulnya hutan sebaiknya diganti menjadi penebangan pohon sampai hutan menjadi gundul agar kalimat tersebut menjadi paralel. Kata sungai yang sudah tidak teratur lagimerupakan kalimat yang tidak logis sebaiknya di ganti dengan kata pencemaran air di sungai. Selanjutnya kata akan tetapi gundulnya hutan tersebut juga dihilangkan karena kalimat yang serupa sudah disebutkan di depannya.Bentuk yang benar: Banjir sering terjadi disebabkan olehpenebangan pohon sampai hutan menjadi gundul dan pencemaran air di sungai.

\section{g. Kalimat yang Ambiguitas}

Kesalahan ini tidak ada ditemukan dalam teks yang ditulis siswa. Hal ini menunjukkan bahwa siswa sudah memahami kalimat yang ambigu.

\section{h. Penghilangan Konjungsi}

Penghilangan konjungsi pada kalimat "Kita tidak menyadari (...)setiap hari terjadi penumpukan sampah.”(T16.P2.K1)Konjungsi yang tepat untuk melengkapi kalimat tersebut adalah bahwa karena untuk menyatakan isi atau uraian bagian kalimat yang di depan. Bentuk yang benar:Kita tidak menyadari bahwa setiap hari terjadi penumpukan sampah.

\section{i. Penggunaan Konjungsi yang Berlebihan}

Penggunaan konjungsi yang berlebihan dalam kalimat "Untuk menghindari banyak korban, maka perlu dilakukan usaha-usaha penanggulangan bencana.(T2.P4.K2)Untuk merupakan konjungsi yang menyatakan tujuan atau maksud, sedangkan makamerupakan konjungsi yang menyatakan akibat. Konjungsi tersebut seharusnya digunakan salah satu saja yang sesuai dengan kaidah bahasa agar menjadi kalimat yangefektif (baku).Bentuk yang benar: Untuk menghindari banyak korban, perlu dilakukan usaha-usaha penanggulangan bencana.

\section{j. Urutan yang Tidak Paralel}

Urutan yang tidak paralel pada kalimat "Pelayanan dasar itu dapat diwujudkan dengan meningkatkan sumber air bersih, memperbaiki rumah dan penyediaan usaha."(T9.P4.K2)Kata-kata yang dicetak miring pada masing- 
masing kalimat di atas merupakan rincian. Kalimat yang terdapat rincian diusahakan rinciannya harus paralel.Bentuk yang benar:Pelayanan dasar itu dapat diwujudkan dengan peningkatan sumber air bersih, perbaikan rumah, dan penyediaan usaha.

\section{k. Penggunaan Istilah Asing}

Penggunaan istilah asing pada kalimat "Jenis awan berlapis-lapis ini menjulang ke arah vertikal sampai ketinggian 30.000 feet." (T5.P3.K3)Istilah asing yang dicetak miring pada kalimat tersebutharus diganti dengan istilah dalam bahasa Indonesia agar menjadi kalimat yang baku.Bentuk yang benar:Jenis awan berlapis-lapis ini menjulang ke arah vertikal sampai ketinggian 30.000 kaki.

\section{Penggunaan Kata Tanya yang Tidak Perlu}

Penggunaan kata tanya yang tidak perlu pada kalimat "Gunung berapi adalah sebuah titik pusat yang mana sewaktu-waktu dapat meletus."(T2.P1.K1)Bentuk yang mana sejajar dengan penggunaan which. Dalam bahasa Indonesia sudah ada penghubung yang lebih tepat yaitu kata yang.Bentuk yang benar:Gunung berapi adalah sebuah titik pusat yang sewaktu-waktu dapat meletus.

Berdasarkan analisis yang telah dilakukan menunjukkan bahwa dalam menulis teks eksplanasi siswa cenderung melakukan kesalahan pada penggunaan preposisi yang tidak tepat dan penggunaan kalimat yang tidak lengkap. Kesalahan tersebut terjadi karena siswa kurang mempelajari materi mengenai sintaksis atau tata kalimat. Kurangnya pemahaman mengenai aturan dalam menulis sesuai kaidah bahasa Indonesia yang baik dan benar menjadi penyebab utama munculnya kesalahan sintaksis dalam teks eksplanasi.

Jumlah keseluruhan kalimat yang mengandung kesalahan sintaksis yaitu 142 kalimat dengan rincian kesalahan sintaksis berupa penggunaan frasa sejumlah 61 kalimat $(42,95 \%)$ dengan enam faktor penyebab. Jumlah kalimat yang mengandung kesalahan sintaksis berupa penggunaan kalimat sejumlah 81 kalimat $(57,04 \%)$ dengan sebelas faktor penyebab. 


\section{PENUTUP}

Kesalahan sintaksis berupapenggunaan frasadalam teks eksplanasi siswa kelas XI SMA Negeri 3 Medan Tahun Pembelajaran 2016/2017sejumlah 61 kalimat $(42,95 \%)$. Kesalahansintaksis berupa penggunaan kalimatdalam teks eksplanasi siswa kelas XI SMA Negeri 3 Medan Tahun Pembelajaran 2016/2017sejumlah 81 kalimat (57,04\%).

Peneliti memaparkan beberapa saran berikut. 1) Dengan adanya penelitian ini diharapkan siswa mampu mengetahui bentuk kesalahan penggunaan frasa dan penggunaan kalimat dalam teks agar dapat mengurangi kesalahan siswa dalam menulis guna mendapatkan teks yang baik. 2) Pemahaman siswa tentang kaidah penggunaan frasa dan penggunaan kalimat masih kurang. Oleh karena itu, guru bahasa Indonesia hendaknya lebih sering memberikan latihan menulis dengan memperhatikan aspek-aspek kesalahan penggunaan frasa dan kalimat dalam teks siswa. 3) Hasil penelitian ini dapat digunakan untuk mengembangkan penelitian lanjutan yang sejenis.

\section{DAFTAR PUSTAKA}

Kosasih, E. 2014.Jenis-Jenis Teks.Bandung: Yrama Widya.

Mahsun. 2014. Teks dalam Pembelajaran Bahasa Indonesia Kurikulum 2013.Jakarta: PT Raja Grafindo Persada.

Moleong, Lexy J. 2009. Metodologi Penelitian Kualitatif: Edisi Revisi. Bandung: Rosdakarya.

Setyawati, Nanik. 2013. Analisis Kesalahan Berbahasa Indonesia: Teori dan Praktik. Surakarta: Yuma Pustaka.

Istinganah, Nurul. 2012. Analisis Kesalahan Sintaksis pada Karangan Narasi Ekspositoris Siswa KelasVIII SMP Negeri 1 Banguntapan, Bantul, Yogyakarta.Yogyakarta: Skripsi UNY.

Wardani, Kusuma. 2016. Analisis Kesalahan Berbahasa pada Bidang Sintaksis dalam Karangan Deskripsi Siswa Kelas X SMK Pelita Bangsa Boyolali. Surakarta: Jurnal Universitas Muhammadiyah Surakarta. 